\title{
The Role of Law Professionals to Encounter Technology in The Era of Industrial Revolution 4.0
}

\author{
Edis on H Manurung \\ \{edisonmanurung2010@yahoo.com\}
}

Doctoral School of Law, Universitas 17 Agust us 1945 Jakarta, Jakarta, Indonesia

\begin{abstract}
The Fourth Industrial Revolution has brought new challenges to the law world view. The presence of the industrial revolution 4.0 through connectivity and digitalization can improve the efficiency of manufacturing chain and the quality of production. In vise versa the digitalization of the industrial sector has a negative impact on employment and disrupts the conventional businesses. The objectives of this research are to determine the impact of the development of industrial digitalization on the conventional job place especially in law professions. This research employs a qualitative method through a normative juridical approach by mastering the law for a particular problem and how to implement the related regulations legally. The research results informed that the industrial technology 4.0 era are focused on the absorption of conventional manpower which are more or less affecting the absorption of current legal professionals; and in order to counterbalance this issue, the legal professionals have to improve their skills, knowledge, and field specializations. The rationale of this is that every professionals must be capable to meet the needs of their clients and to fulfill their responsibility. Therefore, working quality of the every professionals need to reflect on their attitudes, honesty, sincerities, cleanliness, dignities, and responsibility in ethical behaviors.
\end{abstract}

Keywords : era 4.0, technology, legal professional, role

\section{Introduction}

In the past two decades, information technology have developed rapidly and changed various settings of human life. Changes in information technology are driven by business sectors that evolve continuously and adapt to the rapid changes. The businesses in their process of production, distribution and consumption activities naturally and continuously find a way to reduce costs and profitable, and also pursue better effectiveness, efficiency and convenience.

Yet, the massive changes and dynamic development of information technology have not been followed by the development of the law. It moves slowly to catch up with the technology advances as according to the Dutch adage to be able to recap, er de feiten aan. Whereas known that Indonesia is a based on law country. The consequence is that law to be used as a foundation to develop the economics. Economic development should not be separated from law development because economics and law are interconnecting subjects [1].

Industry 4.0 is the fourth industrial period which in various literatures defines that the industrial stages are divided as follows:

1. Stage 1: Industries that have already used mechanical machines which started since the invention of the steamengines.

2. Stage 2: Industries that have utilized electricity which was indicated within mass productions;

3. Stage 3: Industries that have used computers and automation systems;

4. Stage 4: Industries thathave utilized cyber space. 
The presence of the fourth industrial revolution era (Industry 4.0) is inevitable. Indones ia needs to prepare strategic steps to be able to adapt to this era of the digital industry. Indonesia is committed to develop global competitive manufacturing industries through accelerating the implementation of Industry 4.0. By implementing Industry 4.0, the Minister of Industry is targeting that the national aspirations can be achieved. Industry 4.0 through connectivity and digitalization can improve the efficiency of manufacturing chains and the quality of production. In vise versa the digitalization of the industrial sector have neg ative impacts on employment and disrupts the conventional businesses. The government must anticipate the negative impacts of Industry 4.0. When the govemment decides to adapt to the Industrial 4.0 system, the govemment must also consider its sustainability. The implementation of this digital industry systemles t becomes a burden only because it was not utilized optimally.

\section{A. Research Problems}

Base on the background described above, the research problems discussed in this paper are:

1. What is the impact of industrial digitalization on the employment especially in law professions?

2. How to realize prospected human resources in law professions to encounter the era of indus trial technology 4.0 ?

\section{B. Research Objectives}

1. To determine the impact of the development of industrial digitalization on the conventional job place especially in law professions?

2. How to create prospected legal professionals to encounter the era of industrial technology 4.0 ?

\section{Research Benefits}

1. To discover the impact of the development of industrial digitalization on the conventional job place especially in law profession.

2. As an input to legal professionals to create prospected legal professionals to encounter the era of industrial technology 4.0 to compete with Artificial Intelligences.

\section{Theoretical Review}

\section{Definition of IndustrialRevolution}

Referring to several literatures of Great Dictionary of the Indonesian Language (abbreviated in English and Indonesian as KBBI) the industrial revolution cons ists of two words : revolution and industry [2]. Revolution defines as changes occur very fast, while the notion of industry defines as efforts to carry out the production process. The common thread of industrial revolution defines a change that takes place quickly in the production process where the production process originally was done by humans' labor then replaced by machines, and it gives commercial value added to the goods. The industrial revolution has changed the way humans' works frommanual to automation or digitalization.

The term "Industrial Revolution" was introduced by Friedrich Engels and Lou is -Auguste Blanqui in the mid-19th century. The industrial revolution is still running from time to time. The latest decade has been entering and called as the fourth phase (4.0). The changes from phase to phase give differences articulately in terms of their use. The first phase (1.0) is 
concemed with the discovery of a machine which was stressing on the mechanization of production. The second phase (2.0) shifted to the mass production level which integrated with quality control and standardization. The third phase (3.0) entered the stage of mass uniformity which relied on computerized integration. The fourth phase (4.0) presents digitalization and automation of internet integration with manufacturing.

The definition of industrial revolution was also stated by Arnold Toynbee in his book Lectures On Industrial Revolution (London: Rivingston, 1884). The content of this book is a description of the industrial revolution and its influences on policy, the mechanization of production, cultures, and the system of finance in the world, especially Europe. The initial outset was the discovery of a steam engine by James Watt. Then, the industrial revolution 2.0 was marked with the discovery of electricity, and the industrial revolution 3.0 was marked with the invention of computers. Early of the $21^{\text {st }}$ century, the discovery of the intemet and information technology (IT) initiated the birth of the industrial revolution 4.0.

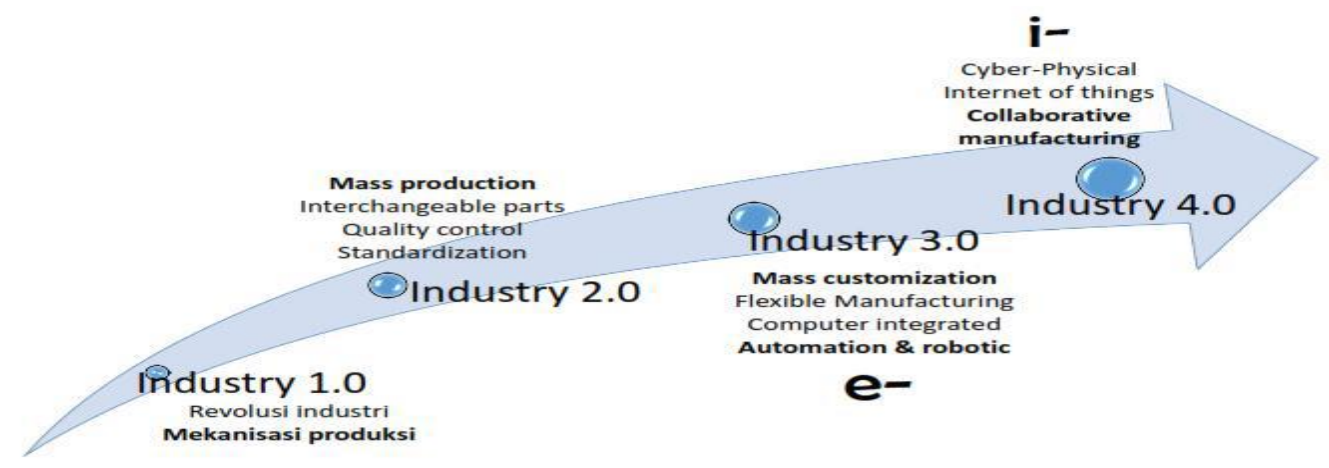

Fig.1. Image of the industrial revolution

The term of industry 4.0 was first introduced in the Hannover Fair, Germany in 2011 when the term of industry 4.0 was introduced. In the beginning the term of industry 4.0 was the name of the initiation of Germany govemment's technology strategy towards the year of 2020. In the literature review conducted by a research team of the University of Dortmund, Germany (Hermann, Mario Pentek, Tobias Otto and Boris, 2015) found several key concepts in the term of industry 4.0, they defined that the concepts were the component of industry 4.0: (1) Cyberphysical system (CPS); (2) Internet of Things (IoT); (3) Intemet of Services (IoS); and (4) Smart Factory. Base on those key components, Hermann et. al., defined industry 4.0 as follows

"We define Industrie 4.0 as follows: Industrie 4.0 is a collective term for technologies and concepts of value chain organization. Within the modular structured Smart Factories of Industrie 4.0, CPS monitor physical processes, create a virtual copy of the physical world and make decentralized decisions. Over the IoT, CPS communicate and cooperate with each other and humans in real time. Via the IoS, both internal and cross-organizational services are offered and utilized by participants of the value chain."

According to Prof. Dr. John Pieris "Industrial Revolution 4.0 has 4 (four) characteristics. They are: (1) simple and uncomplicated; olden when played games, only one device for one 
game; now with Android technology, one device for thousands and even millions of games; (2) faster, at anytime, and from anywhere among countries; in the past, to graduate from a university in America, for instance the Harvard University, you must go to America. Now, you can enroll via its web; (3) cheaper, and (4) accessible; access is a wealth of information,". The Industrial Revolution 4.0 initiates the changes which take place very quickly. Therefore, Prof. Dr. John Pieris states that: "the people and its govemment of each country must have legal intelligence to respond to this industrial revolution era. Law must be responsive to these changes, desires, and needs. However, the fundamental aspects of law, such as ethics, morals, and norms or rules to the said law must be maintained by the country, people and its govemment. While the regulations its elf should have flexibility to respond to changes and new civilizations."

\section{Research Method}

This research employs a qualitative method through a normative juridical approach by mastering the law for a particular problem and how to implement the related regulations

| legally. The normative juridical approach includes research-_in the legal system, legal synchronization degree, legal history and law comparison. Normative juridical approach is also called a library res earch in law which is conducted by examining existing literature.

\section{The Body of Law}

The body of law used in this study is legal matters consisting of primary legal references, such as legislations, binding and permanent legal force of judicial (court) decisions; and secondary legal references such as books, literatures, bills and scientific publications in jurisprudence, which relate to the research topics and can be used to answer the research problems; and tertiary legal references such as scientific publication in non-jurisprudence i.e. encyclopedias, law dictionaries, Indonesian and Dutch language dictionaries as well as other references relate to the study. All legal references are to be arranged systematically, reviewed and concluded in relation to the research problems.

\section{Result and Discussions}

\section{A. The impact of the development of industrial digitalization on the conventional job place especially in law professions.}

The world is currently facing the fourth industry change which is known as Industry 4.0. Base on the Mckinsey Global Institute analysis, Industry 4.0 has a very large and broad impact, especially in the employment sector, where robots and machines will eliminate many jobs in | the world. The industrial revolution-_era must be addressed by industrial players wisely and carefully. The industrial era through the connectivity and digitalization can improve the efficiency of manufacturing chain and the quality of production. However, vise verse the industrial revolution era will also eliminate 800 million jobs worldwide until 2030 because those jobs will be taken overby robots. It could be a threat to Indonesia as a country that has a high labor force and unemployment rate. The govemment needs to anticipate these changes appropriately through the strategies that can increase the competitive industries nationally in line with the creation broader employment opportunities.

The variety of businesses that continuous ly lead to the digitalization, create attentions to use robots. The using of electronic devices compel the companies terminate employment. Base on 
the results of a study stated that in the next 10 years at least 40 percent of labor will be replaced by robots and machines. The circumstances have put people to be more creative in order to survive in their own jobs. In fact, new professions are to be created by humans to adapt in the robotic era. The direction of climate changes in industry has been people concem since 1980 . It also initiates robots with artificial intelligence take on the role of lawyers.

The response generated even includes a number of references and quotes to support the conclusions. ROSS also leams from experience so it is faster and smarter for more interactions. "You ask questions in plain English, as you would a colleague and ROSS then reads through the entire body of law and retums a cited ans wer and topical readings from legis lation, case law and secondary sources. In addition, ROSS monitors the law around the clock to notify you of new court decisions that can affect your case." Bob Craig, CIO (Chief Information Officer) at Baker \& Hostetler, explains the rationale behind the decision to hire the robot. "At Baker Hostetler, we believe that emerging technologies like cognitive computing and other forms of machine learning can help enhance the services we deliver to our clients."

Besides ROSS, entering the industrial era 4.0, varieties of Artificial Intelligence (AI) products begin to emerge. The existence of a legal robot with the most sophisticated analytical capabilities, high accuracy to be able to finish the work in just seconds. LawGeex, the AI startup platform provider for analyzing legal documents from the United States, recently conducted a study. The study involving a number of law professors from Stanford University, Duke University School of Law, and the University of Southem California was conducted to test the technological capabilities of LawGeex in reviewing legal documents.

Twenty experienced attorneys competed against the three-year-old AI of LawGeex. Within four hours, they must analyze five non-disclosure agreements (NDA) and 30 other legal issues, including arbitration and compensation. Who is the winner?

As a result, AI made by LawGeex won by a nose. In terms of accuracy, the team of attorneys has an average of 85 percent, while LawGeex has an average accuracy of 95 percent. In fact, in the process of identifying one contract, LawGeex's accuracy reached 100 percent, while the accuracy obtained by the attorney team was "only" at 97 percent. In terms of time, AI proved to be able to complete tasks in a much faster time. The average team of lawyers takes 92 minutes. Mean while, LawGeex can solve it in just 26 seconds. To have the capabilities that can be said to exceed humans, LawGeex intens ively trains their algorithms. They train AI with tens of thousands of contracts or agreements, and utilize the special machine learning and deep learning technologies.

Although it has a very high level of accuracy and speed, which even can surpass humans, but AI could not be able to completely replace humans. So, the existence of AI does not really need to be considered a threat that will take over a human career. To support this view, a report from LawGeex claims that people will be surpris ed to find out that AI can work much faster than lawyers in certain tasks. However, in general, machines cannot compete with the ability of human thinking to work on a number of fundamental legal activities, especially in making decisions. This condition makes law-learners understand other sciences that become supports to the jurisprudence and they must have multi skills in other fields in order to innovate in encountering of technological advances to deliver benefits to society while guiding the development of technology business for the law. 


\section{B. Creating prospected legal professionals to encounter the era of Technology Industry 4.0 in order to compete with AI}

The industrial revolution 4.0 is characterized by a pattem of digital economy, artificial intelligence, big data, robotic and so on, which are generally described as changes in work methods that focus on data management, industrial work systems through advancing technology, communication and improving work efficiency related to the human interaction. Data becomes the main needs in the comporate decision making processes which are supported by computerized capabilities and unlimited data storage systems. The logical consequences or the impact of the changes arise from this era also afflict legal professionals to improve the quality of profession competitively and productively. The presence of legal professionals (legal consultants) who are able to compete in the era of technology 4.0 are still needed.

Good legal professionals must have moral and be professional in carrying out their obligations and responsibilities. Before expecting to build a society that aware and law-abiding, it is the legal professionals' obligation to provide a good role model. Without a good role model, it is difficult to expect the society to be aware of and law-abiding. For this model of attitude, the human resources must have: 1) attitude of humanitarian, so that the pers on does not only respond to the law formally; 2) attitude of a just, to find out what is appropriate for the society;3) attitude of propriety, need to consider of what is truly just in a concrete case.

The legal professionals in the era of industry 4.0, must also pay attention beyond the relations with others people in case of human nature interacts within the society, which will bring up three habits, they are: communication skills, positive thinking and balance. Formatting habits base on three interrelated elements, which are: the element of knowledge (what must be done), expertise (how to do it), and desire (motivation or encourage to do). Without these three elements radically, we cannot say that we are used to a habit. Furthermore, the legal professionals in the industrial 4.0 eras also needs to realize that in carrying out the duties, to consider a religious foundation, which reflexes the profession as a social duty and at the same time as devoting the love for God Almighty with concrete actions. It means that to carry out law professions and its functions must always refer to the pupose of the law to deliver care for every people to create justice, which relies on human dignity. Carrying out the profession, demands high moral from the perpetrators.

Thus, to be capable to carry out society legal services and participate in the design of the society orders in creating public safety, legal professionals ideally required to fulfill certain standards: 1) professional ability which includes the ability in law technically and in trial procedurally to carry out their duties; 2) personal integrity which means free of conflict interests to maintain objectivity and independence; 3) discipline which includes speed and determination to carry out their duties; and 4) possess idealism and vision to direct professional abilities for the interests of enforcing the aspiration of law within the development of society which is always actual.

\section{Conclusion}

The industry 4.0 has very large and wide impacts, especially in the employment sector, where robots and machines will eliminate many job-types in the world. The industrial revolution era must be addressed by industrial players wisely and carefully. The industrial era through connectivity and digitalization can improve the efficiency of manufacturing chain and the quality of production. In vise vers a this industrial revolution will also eliminate 800 million jobs world wide until 2030 because those jobs will be taken over by robots. It was indicated by inventing ROSS and AI, when they were compared with people abilities, they are still superior 
in terms of speed and accuracy. However, in general, machines cannot compete with the ability of the people to think of doing a number of fundamental legal activities, especially in making decisions.

To realize prospected human resources in law profession to encounter the era of industrial technology 4.0, the professionals as law profession must have expertise that relate to their knowledge, especially in their fields, because every professional must be able to meet the needs of society in need of their services, and possess a personality which is fully responsible for the service they deliver. Thus, the quality of professionals is reflected in attitudes that uphold honesty, truth, and justice, clean, dignified and responsible.

The era of industrial revolution 4.0 must be addressed by industry players wisely and carefully, because the progress of the industrial revolution can be detrimental to conventional labors which may cause unemployment everywhere. In addition, the leg is lation also must be clear to determine the percentage of conventional labors and using robots in a company or industry, so the concerns will not arise.

The legal professionals are also to be aware and submissive to the law because they need to show a good role model before expecting the creation of a society that is aware and lawabiding. Without this model, it is difficult to expect a society with good awareness and submissive to the law.

\section{References}

[1] A. Sulistiyono and Rustamaji, Hukum Ekonomi sebagai Panglima. Surabaya: Masmedia Buana Pustaka, 2009.

[2] Pusat Bahasa, Kamus Besar Bahasa Indonesia. Jakarta: Balai Pustaka, 2007. 